\title{
Does the Inviolability of Archives Lead to a Catch-22 Situation?*
}

\section{Karen Kaiser**}

\section{ABSTRACT}

In contrast to Joseph Heller's novel 'Catch-22', the illogical or paradoxical situation arising from the privilege of inviolability of archives in international organisations' cooperation with national in the fight against fraud and corruption is one of different legal orders that are not necessarily aligned from the outset. National law enforcement and judicial authorities have to respect the privilege of inviolability of archives enjoyed by international organisations. They may neither interpret the privilege restrictively without taking full account at the same time of the purpose of privileges, i.e. the orderIy and independent operation of international organisations, nor generally limit the privilege in any other way. It therefore lies in the hands of international organisations themselves to limit the risk of a catch-22 situation arising from the privilege of inviolability of archives in their cooperation with national authorities. However, the onus is not only on international organisations. Any reasonable use of the privilege presupposes that national law enforcement and judicial authorities acknowledge its existence and deal with it respectfully.

KEY WORDS: Confidentiality, fight against corruption, human rights violations, international organizations.

\section{RESUMEN}

A diferencia de la novela de Joseph Heller 'Trampa 22', la situación ilógica o paradójica que surge del privilegio de inviolabilidad de los archivos dentro de la cooperación de organizaciones internacionales con autoridades nacionales en el marco de la lucha contra el fraude y la corrupción es uno de los diferentes órdenes jurídicos que no necesariamente están alineados desde el principio. Las autoridades nacionales tienen que respetar la inviolabilidad de los archivos de organizaciones internacionales y no pueden ni interpretar el privilegio de manera restrictiva, sin tomar en cuenta al mismo tiempo su propósito, que es la operación ordenada e independiente de las organizaciones internacionales; $y$ tampoco limitar el privilegio de alguna otra manera. Por lo tanto, queda en manos de las organizaciones internacionales en si mismas el limitar el riesgo de una situación de Trampa 22, al cumplir con su deber de cooperar con autoridades nacionales. Sin embargo, la carga de la prueba no solo recae en las organizaciones internacionales. Cualquier uso razonable del privilegio presupone que las autoridades nacionales reconocen su existencia y la abordan de manera respetuosa.

PALABRAS CLAVE: Confidencialidad, lucha contra la corrupción, violaciones de derechos humanos, organizaciones internacionales.

* Artículo recibido el 6 de diciembre de 2016 y aceptado el 20 de febrero de 2017.

** Banco Central Europeo. (Karen.Kaiser@ecb.europa.eu) 


\section{SUMARIO}

1. Facts and main conclusions of the judgment in World Bank v. Wallace

a. Legal nature and scope of the privilege of inviolability of archives

b. How the potential of the privilege of inviolability of archives may lead to a catch-22 situation

2. Rules mitigating the risk of a catch-22 situation

a. National level

b. International level

3. Conclusion

"You mean there's a catch?" "Sure there's a catch," Doc Daneeka replied. "Catch-22. Anyone who wants to get out of combat duty isn't really crazy." Joseph Heller, Catch-22, Chapter 5

The term 'catch-22' was coined by Joseph Heller in his 1961 novel 'Catch-22' which describes absurd bureaucratic constraints on soldiers in World War II. One of the characters in the novel, an army psychiatrist, invokes 'catch 22' to explain why any pilot requesting mental evaluation for insanity -hoping to be found not sane enough to fly and thereby escape dangerous missions- demonstrates his own sanity in making the request and, thus, cannot be declared insane. In the meantime, the term 'catch-22' has filtered into common usage in the English language. Strictly speaking, it means a problematic situation for which the only solution is denied by a circumstance inherent in the problem or by a rule, but it is also more generally defined as any illogical or paradoxical problem or situation.

This article analyses whether the inviolability of international organisations' archives could lead to a catch-22 situation in their cooperation with national law enforcement authorities in the fight against fraud and corruption. It, thus, examines whether there is a problematic situation (fraud and corruption often transcends borders) for which the only solution (international organisations cooperating with national law enforcement authorities) is denied by a circumstance inherent in the problem or by a rule (the inviolability of archives). In order to have a reference point to demonstrate how the potential of the inviolability of archives may lead to a catch-22 situation, this article first summarises the facts and main conclusions of the recent judgment of the Supreme 
Court of Canada in World Bank Group $v$ Wallace. ${ }^{1}$ Based on the assumption that such potential exists, this article then explores whether there are other rules, apart from the inviolability of archives, that could mitigate the risk of a catch-22 situation on the national or international level.

\section{Facts and main conclusions of the judgment in World Bank Group v. Wallace}

In line with its official policy to fight fraud and corruption in World Bank Group-financed projects and/or against World Bank Group staff, the World Bank Group ${ }^{2}$ has collaborated with national law enforcement authorities and shared information gathered from informants across the world since the 1990's. In the case of World Bank Group v. Wallace, the World Bank Group's anti-fraud/anti-corruption investigative unit, the Integrity Vice-Presidency (hereinafter INT), investigated whistleblower allegations asserting that executives of an international corporation had attempted to bribe officials of the Government of Bangladesh in the hope of securing a multi-billion dollar construction contract. After completing its investigation, the INT provided copies of whistleblower emails, investigation reports and other related documents to the Canadian law enforcement authorities.

After the Canadian law enforcement authorities had obtained wiretap authorisations in furtherance of obtaining direct evidence of the accused executives' involvement in the alleged corruption, Kevin Wallace, one the accused executives, brought a pre-trial motion to the Ontario Superior Court of Justice. With this motion, he requested that the trial judge order the World Bank Group to produce certain documents in its possession in order to use these as evidence in a motion to contest the wiretap authorisations. The Canadian trial judge granted the application. However, on appeal of the World Bank Group, the Supreme Court of Canada set aside the trial judge's decision and upheld the inviolability of the World Bank Group's archives. The World Bank Group could not be compelled to produce documents by a national court.

\footnotetext{
1 Supreme Court of Canada, World Bank Group v. Wallace, 2016, scc 15, 2016 1 S.C.R. 207. Disponible en: https:// scc-csc.lexum.com/scc-csc/scc-csc/en/item/15915/index.do

${ }^{2}$ The World Bank Group is a family of five international organisations: the International Bank for Reconstruction and Development (hereinafter IBRD), the International Development Association (hereinafter IDA), the International Finance Corporation, the Multilateral Investment Guarantee Agency and the International Centre for Settlement of Investment Disputes. The World Bank comprises the IBRD and the IDA.
} 
In order to put the judgment of the Supreme Court of Canada in context and understand how the potential of the privilege of inviolability of archives may lead to a catch-22 situation, it is helpful to explain the legal nature and scope of the privilege of inviolability of archives.

\section{a. Legal nature and scope of the privilege of inviolability of archives}

The inviolability of archives is a privilege enjoyed by international organisations, generally on the basis of public international law, such as pursuant to Section 5 of Article VII of the IBRD's and Section 5 of Article VIII of the IDA's Articles of Agreement, ${ }^{3}$ and exceptionally on the basis of national law, such as pursuant to Section 2(c) of the United States International Organisations Immunities Act. ${ }^{4}$ In contrast to immunities which have no impact on the applicability of national law but which hinder national authorities, especially national courts, in assessing the existing legal situation, privileges affect the national substantive or procedural law by making exceptions or modifications for international organisations. ${ }^{5}$

In the case of the inviolability of archives, the privilege shields the entire collection of information belonging to or held by international organisations, irrespective of $a$ ) the medium, $b$ ) whether the information is classified and c) where it is located, ${ }^{6}$ from any unilateral interference by national authorities, ${ }^{7}$ i.e. from search, seizure and compelled production. The Supreme Court of Canada, inter alia, clarifies in World Bank Group v. Wallace that the plain and ordinary meaning of the term "archives" does not differentiate between historical

\footnotetext{
${ }^{3}$ Section 5 of Article VII of the IBRD's and Section 5 of Article VIII of the IDA's Articles of Agreement read: "The archives of the Bank/the Association shall be inviolable". Articles of Agreement of the International Bank for Reconstruction and Development, unTS, vol. 2, p. 13; Articles of Agreement of the International Development Agency, UNTS, vol. 439, p. 249).

${ }^{4}$ Pub.L. 79 291, 59 Stat. 669, H.R. 4489, enacted December 29, 1945.

${ }^{5}$ MöLdNER, MIRKA, "International Organizations or Institutions, Privileges and Immunities", en Rüdiger Wolfrum (ed.), Max Planck Encyclopedia of Public International Law. párr. 1. Disponible en: http://opil.ouplaw.com

${ }^{6}$ Article $1(1)(k)$ of the Vienna Convention on Consular Relations defines "consular archives" as including "all the papers, documents, correspondence, books, films, tapes and registers of the consular post, together with the ciphers and codes, the card-indexes and any article of furniture intended for their protection or safe keeping". Vienna Convention on Consular Relations, UNTS, vol. 596, p. 261. Article ॥ Section 4 of the Convention on the Privileges and Immunities of the United Nations (hereinafter cPIUn) moreover expressly lays down that the "archives of the United Nations, and in general all documents belonging to it or held by it, shall be inviolable wherever located". Convention on the Privileges and Immunities of the United Nations, UNTS, vol. 1, p. 15).

${ }^{7}$ See Court of Appeal for England and Wales, R. (Bancoult) v. Secretary of State for Foreign and Commonwealth Affairs (No. 3), 2014 EWCA Civ 708, 1 W.L.R. 2921. párr. 61.
} 
and current or classified and unclassified documents or records. ${ }^{8}$ It also sheds light on the meaning of the term "inviolability".

Originating in the law of diplomacy, and later becoming common in the founding treaties of international organisations, the term "inviolability" implies freedom from unilateral interference on the part of the State. This interpretation not only finds support in the case-law of national courts, ${ }^{9}$ but also in international legal doctrine. ${ }^{10}$ The inviolability of archives is said to afford a complete shield from investigation, confiscation or interference of any kind with the information belonging to the archives of an international organisation.

\section{b. How the potential of the privilege of inviolability of archives may lead to a catch-22 situation}

This broad interpretation is justified by the purpose of the privilege of inviolability of archives. As international organisations do not have any sovereign territory of their own and are, thus, vulnerable to interference by national authorities, shielding the entire collection of information belonging to or held by international organisations from coercive measures by national authorities is integral to ensuring the proper and independent functioning of such organisations. Whilst the Supreme Court of Canada in World Bank Group v. Wallace, thus, did not err setting aside the trial judge's judgment and referring to the privilege of inviolability of archives enjoyed by the World Bank Group, the outcome might nevertheless lead to a catch-22 situation. ${ }^{11}$

On the basis of the information provided by the INT, the Canadian law enforcement authorities obtained wiretap authorisations against the accused executives. However, a completely different question is whether the information provided by the INT would also be sufficient to convict the accused. Pursuant to Section 11(d) of the Canadian Charter of Rights and Freedoms, the accused executives would be presumed innocent, until the prosecution proves beyond a reasonable doubt that they are guilty.

\footnotetext{
${ }^{8}$ Supreme Court of Canada, World Bank Group v. Wallace, 2016, scc 15, 20161 S.C.R. 207. párr 68 et seq. Disponible en: https://scc-csc.lexum.com/scc-csc/scc-csc/en/item/15915/index.do.

${ }^{9}$ See the references in Supreme Court of Canada, World Bank Group v. Wallace, 2016, scc 15, 2016 1 S.C.R. 207. párr 80. Disponible en: https://scc-csc.lexum.com/scc-csc/scc-csc/en/item/15915/index.do

${ }^{10}$ See e.g. Muller, Alexander Samuel, International Organizations and their Host States, Aspects of their Legal Relationship, La Haya, Kluwer, 1994, p. 205.

"Similarly critical Daher, Ayman \& Sarhan, Alan, "World Bank Group v Wallace: International Organizations' Immunities and their Involvement in the Fight Against Corruption". Disponible en: http://www.brettonwoodslaw. com/world-bank-group-v-wallace-international-organizations-immunities-and-their-involvement-in-the-fight-against-corruption.
} 
If the accused executives can convincingly argue that certain documents in the possession of the World Bank Group contain extenuating circumstances (i.e. they do not conduct a mere "fishing expedition" through the World Bank Group's archives), there is reasonable doubt. In this case, the ultimate goal of the cooperation of international organisations with national law enforcement authorities in the fight against fraud and corruption, i.e. the conviction of fraud and corruption before national courts, could not be obtained because of the inviolability of international organisations' archives.

\section{Rules mitigating the risk of a catch-22 situation?}

At first glance, there is reason to believe that rules mitigating the risk of a catch-22 situation would rather be applied on the national level, i.e. by national authorities, in particular national courts, than on the international level. Although privileges enjoyed by international organisations are rules that are generally imposed upon States on the international level, they require -as explained above - that national substantive or procedural law makes exceptions or modifications for international organisations. As a consequence, privileges are applied on the national level. ${ }^{12}$ The conclusion that any rules counteracting privileges would also rather be applied on the national than on the international level is, therefore, not far-fetched. However, this article argues the opposite, namely that it is in principle not for national authorities to limit the privileges enjoyed by international organisations, but for international organisations to make reasonable use of their privileges.

\section{a. National level}

Possible ways to mitigate the risk of a catch-22 situation arising from the privilege of inviolability of archives in international organisations' cooperation with national law enforcement authorities on the national level could be to either interpret the privilege restrictively or to justify limitations on the privilege by balancing it against other interests, such as the interest to effectively prosecute fraud and corruption.

In the decision that was set aside by the Supreme Court of Canada World Bank Group v. Wallace, the Canadian trial judge made an attempt to interpret the privilege of inviolability of archives restrictively by using two dif-

\footnotetext{
${ }^{12}$ OrakhelashVili, Alexander, "State Immunity in National and International Law: Three Recent Cases Before the European Court of Human Rights", Leiden Journal of International Law, vol. 15, 2002, p. 703, 706.
} 
ferent lines of argumentation. First, the trial judge reasoned that the World Bank Group could not choose to provide some of its documents for use in the criminal prosecution but refuse to provide other relevant documents. ${ }^{13}$ Second, it was found that the World Bank Group had chosen to benefit from Canadian criminal proceedings (it had, for example, sought to obtain materials seized pursuant to the search warrants) and consequently was obliged to accept the associated burdens of doing so, which includes compliance with procedural rules. ${ }^{14}$

Privileges are defined as affecting the national substantive or procedural law by making exceptions and modifications for international organisations and there is a general rule of interpretation in most legal systems that exceptions have to be interpreted restrictively in order to prevent them from rendering the basic obligation ineffective. ${ }^{15}$ However, this rule of interpretation cannot apply with the same force in the international legal order. The reason for this is that the interpretation of international treaties, in particular the founding treaties of international organisations which also lay down the privileges and immunities of international organisations, is generally inspired by the purpose of the treaty and its effective implementation (effet utile). ${ }^{16}$

If international treaties lay down exceptions, it is difficult to apply both rules of interpretation at the same time, as the principle of effectiveness calls for an interpretation that takes full account of the purpose of privileges, i.e. the orderly and independent operation of international organisations. This explains the broad interpretation of the privilege of the inviolability of archives used by the Supreme Court of Canada.

Reasoning - as the Canadian trial judge did - that international organisations may not select the documents they want to share with national law enforcement authorities runs counter to the orderly and independent operation of international organisations, as the underlying assumption is that international organisations' archives can only be given up as a whole. As a consequence,

\footnotetext{
${ }^{13}$ Supreme Court of Canada, World Bank Group v. Wallace, 2016, scc 15, 20161 S.C.R. 207, párr. 27. Disponible en: https://scc-csc.lexum.com/scc-csc/scc-csc/en/item/15915/index.do

${ }^{14}$ Supreme Court of Canada, World Bank Group v. Wallace, 2016, scc 15, 2016, 1 S.C.R. 207, párr. 27. Disponible en: https://scc-csc.lexum.com/scc-csc/scc-csc/en/item/15915/index.do

${ }^{15}$ See e.g. Court of Justice of the European Union, Judgment of 17 June 1981, Case 113/80, Commission v. Ireland, EU:C:1981:139: párr. 7: "Article 36 of the Treaty 'constitutes a derogation from the basic rule that all obstacles to the free movement of goods between Member States shall be eliminated and must be interpreted strictly', the exceptions listed therein cannot be extended to cases other than those specifically laid down".

${ }^{16}$ Herdegen, Matthias, "Interpretation in International Law", en Rüdiger Wolfrum (ed.), Max Planck Encyclopedia of Public International Law, párr. 30. Disponible en: http://opil.ouplaw.com
} 
this reasoning also has an impact on international organisations' cooperation in the fight against fraud and corruption as international organisations are well-advised not to cooperate under these circumstances. Finding that international organisations subordinate themselves to the national legal order as soon as they share information with national law enforcement authorities has the same detrimental effect on cooperation. Interpreting the privilege of inviolability of archives enjoyed by international organisations in the way the Canadian trial judge did, thus, mitigates the risk of a catch-22 situation, but only by getting rid of the incentive for international organisations to cooperate with national law enforcement authorities in the first place.

With regard to the second possibility to mitigate the risk of a catch-22 situation, namely to justify limitations on the privilege by balancing them against other interests, it is helpful to distinguish between interests of a national nature and interests of an international nature.

The privilege of inviolability of archives may not be balanced against and, as a consequence, limited on the basis of national interests. As mentioned earlier, this privilege shields the entire collection of information belonging to or held by international organisations from any interference by national authorities. Any balancing of the interest of international organisations in having their archives protected by national authorities against national interests, such as the national interest to effectively prosecute fraud and corruption, would, therefore, not only constitute a unilateral interference with international organisations' archives by national authorities, but would also call into question the purpose of privileges, i.e. the orderly and independent operation of international organisations. If the inviolability of archives could be balanced against and, as a consequence, limited on the basis of the national interests of the -in case of the World Bank Group189/173 Member States (IBRD/IDA), the privilege would be largely ineffective.

Considering that even limitations to most human rights can be justified, ${ }^{17}$ this absolute protection of international organisations' archives in the national legal order might seem surprising. However, two considerations need to be tak190 en into account. First, the national interest to effectively prosecute fraud and corruption is not itself an interest which overrides any other interest in the national legal order. Most legal systems have rules which grant a privileged status to certain categories of persons who possess certain information. Well-known privileges are the information privileges in the doctor-patient relationship and

\footnotetext{
${ }^{17}$ In the European Union, for example, only human dignity enjoys absolute protection. Article 1 of the Charter of Fundamental Rights of the European Union reads: "Human dignity is inviolable. It must be respected and protected". Charter of Fundamental Rights of the European Union, OJ C 202, 7.6.2016, p. 389.
} 
the sacerdotal privilege granted to religious representatives.

The privilege of inviolability of archives enjoyed by international organisations can, thus, to a certain degree be compared to these information privileges under national law. ${ }^{18}$ The main difference is that the privilege of inviolability of archives is not the outcome of a balancing of different interests by the national legislature, but rather of the international legal order becoming relevant in the national legal order. Second, the fact that the privilege of inviolability of archives may not be limited on the basis of national interests does not mean that it cannot be limited at all. It should be noted that international organisations' archives might not enjoy absolute protection in the international legal order.

However, the question as to whether the privilege of inviolability of archives may be balanced against and, as a consequence, limited on the basis of international interests on the national level is difficult to answer. On the one hand, there is the rule that "any relevant rules of international law applicable in relations between the parties" ${ }^{19}$ are to be taken into account in the interpretation of international treaties. Interests recognised in public international law, such as, for example, human rights concerns, could, thus, arguably be used to limit the privilege of inviolability of archives enjoyed by international organisations. ${ }^{20}$ As States could avoid their human rights obligations under public international law by channelling certain activities through international organisations, it is argued, at least with regard to immunities of international organisations, that the latter should be limited to the extent that the protection of human rights is weakened. ${ }^{21}$

In the case of Beer and Regan v. Germany and Waite and Kennedy $v$. Germany, the applicants claimed that the application of immunity by a German labour court in an employment dispute against the European Space Agency (hereinafter ESA) infringed their right of access to a court. ${ }^{22}$ The European Court of Human Rights found that, although the right of access to a court was not

\footnotetext{
${ }^{18}$ Muller, Alexander Samuel, "Immunities of icty Staff Members, Assets and Archives before the ictr", en Richard May, et al. (eds), Essays on icty Procedure and Evidence in Honour of Gabrielle Kirk McDonald, La Haya, Kluwer, 2001, pp. 439-440.

${ }^{19}$ Article 31(3)(c) of the Vienna Convention on the Law of the Treaties. Vienna Convention on the Law of the Treaties, UNTS, vol. 1155, p. 331.

${ }^{20}$ Carpanell, Elena, "On the Inviolability of Diplomatic Archives and Documents: The 1961 Vienna Convention on Diplomatic Relations to the Test of Wikileaks", Rivista di diritto internazionale, vol. 98, 2015, pp. 834, 845 et seq.

${ }^{21}$ Möldner, MiRKA, "International Organizations or Institutions, Privileges and Immunities", en Rüdiger Wolfrum (ed.), Max Planck Encyclopedia of Public International Law, párr. 15. Disponible en: http://opil.ouplaw.com

${ }^{22}$ European Court of Human Rights, Judgment of 18 February 1999, Beer and Regan v. Germany, Merits, App No 28934/95, ECHR 6, 1999; European Court of Human Rights, Judgment of 18 February 1999, Waite and Kennedy v. Germany, Merits, App No 26083/94, ECHR 13, 1999.
} 
absolute, the immunity would only be lawful if it pursued a legitimate aim and was proportionate. Since the purpose of the immunity was to enable the ESA to perform its functions efficiently, it pursued a legitimate aim. However, on the question of proportionality, the European Court of Human Rights considered it important that the applicants could avail of reasonable alternative means to protect their rights. This case-law has subsequently been interpreted by certain national courts as requiring an enquiry by a court into the availability and adequacy of alternative remedies provided by an international organisation claiming to benefit from immunity. ${ }^{23}$

On the other hand, it is doubtful whether there are any "relevant rules of international law" that could be used to limit the privilege of inviolability of archives. Unlike immunities, privileges do not hinder national authorities, especially national courts, in assessing the existing legal situation. National courts may be accessed by individuals and may decide on the claims brought irrespective of the privilege of inviolability of archives. If the line of argumentation limiting immunities of international organisations were transferred to privileges, it would probably need to be argued that States could not only avoid their human rights obligations under public international law by channelling certain activities through international organisations, but could also abuse international organisations' archives in order to claim that the information with regard to human rights violations is privileged.

Admittedly, international courts, in particular the Inter-American Court of Human Rights, found on several occasions that States may not resort to secrecy or other judicial bars to impede investigations and proceedings concerning serious human rights violations. ${ }^{24}$ On the basis of this case-law, it has been argued in legal doctrine that the privilege of inviolability of diplomatic archives, which is equally protected under public international law, ${ }^{25}$ may be balanced with and, as a consequence, limited on the basis of human rights concerns

\footnotetext{
${ }^{23}$ Wickremasinghe, Chanaka, "International Organizations or Institutions, Immunities before National Courts", en RüDiger Wolfrum (ed.), Max Planck Encyclopedia of Public International Law, párr. 26 et seq with further references. Disponible en: http://opil.ouplaw.com

${ }^{24}$ See, inter alia, Inter-American Court of Human Rights, Judgment of 25 November 2003, Myrna Mack Chang v. Guatemala, Series C, No. 101, párr. 180 et seq.; Inter-American Court of Human Rights, Judgment of 29 November 2006, La Cantuta v. Peru, Series C, No. 162, párr. 111; Inter-American Court of Human Rights, Judgment 26 September 2008, Tiu Tojin v. Guatemala, Series C, No. 190, párr. 77; Inter-American Court of Human Rights, Judgment of 23 November 2009, Radilla Pacheco v. Mexico, Series C, No. 209, párr. 90 et seq.; Inter-American Court of Human Rights, Judgment of 24 November 2010, Gomes Lund et al. v. Brazil, Series C, No. 219, párr. 202.

${ }^{25}$ Article 24 of the Vienna Convention on Diplomatic Relations: "The archives and documents of the mission shall be inviolable at any time and wherever they may be". Vienna Convention on Diplomatic Relations, unTs, vol. 500, p. 95.
} 
recognized in public international law. ${ }^{26}$ However, it is questionable whether this line of argumentation is persuasive. In the cases that were decided by the Inter-American Court of Human Rights the State accused of a serious human rights violation was the same State relying on secrecy and confidentiality. When the inviolability of diplomatic or international organisations' archives comes into play, an unrelated party to the State accused of a serious human rights violation is involved, namely the sending State or the international organisation. If their privilege was limited, the interpretation of the international treaty granting inviolability of diplomatic or international organisations' archives would no longer rely on "any relevant rules of international law applicable in relations between the parties", but create obligations for a third party without its consent. This is forbidden under public international law. ${ }^{27}$

In order to assess the question as to whether the right to a fair trial of the victim of a serious human rights violation has been infringed, the proportionality of the privilege would probably need to be assessed in line with the reasoning of the European Court of Human Rights in relation to immunities. This assessment would need to take into account not only the rationale for the inviolability of archives which is different from that of national security (which is at the heart of the case-law of the Inter-American Court of Human Rights), but also other considerations. These are the likelihood of the State accused of a serious human rights violation of abusing the privilege of the sending State or international organisation and -in order not to create obligations for a third party- the imputability of this abuse to the sending State or international organisation.

Either way, the question as to whether the privilege of inviolability of international organisations' archives may be balanced against and, as a consequence, limited on the basis of human rights concerns recognized in public international law is not relevant in the concrete case of World Bank Group v. Wallace. Neither the World Bank Group nor a member of the World Bank Group was accused of a serious violation of human rights protected under public international law or an abuse of the World Bank Group's privilege.

\section{b. International level}

On the international level, possible ways to mitigate the risk of a catch-22 sit-

\footnotetext{
${ }^{26}$ Carpanelu, Elena, "On the Inviolability of Diplomatic Archives and Documents: The 1961 Vienna Convention on Diplomatic Relations to the Test of Wikileaks", Rivista di diritto internazionale, vol. 98, 2015, pp. 834, 848 et seq.

${ }^{27}$ Article 34 of the Vienna Convention on the Law of Treaties.
} 
uation arising from the privilege of inviolability of archives in international organisations' cooperation with national law enforcement authorities could be to either establish specific bodies dedicated to the fight against fraud and corruption within international organisations or to benefit from the existence of a possible duty of international organisations to cooperate with national law enforcement and judicial authorities in the specific context of privileges.

Specific bodies dedicated to the fight against fraud and corruption within international organisations such as the World Bank Group's INT or the European Union's European Anti-Fraud Office (hereinafter OLAF) ${ }^{28}$ are established with the objective of setting the administrative or technical foundations for the cooperation of international organisations with national law enforcement and judicial authorities in the fight against fraud and corruption. In order to share information with national law enforcement and judicial authorities, it is necessary to first set up procedures within international organisations in order to collect and verify the information.

However, as the judgment of the Supreme Court of Canada in World Bank Group $v$. Wallace suggests, these specific bodies do not have the potential to mitigate the risk of a catch-22 situation. The reason for this is that they operate "without prejudice to the privileges" of the international organisations concerned. ${ }^{29}$ As long as international organisations do not have any law enforcement powers of their own, even very progressive anti-fraud and anti-corruption bodies established within international organisations depend on cooperation with national law enforcement authorities. Owing to this, these bodies cannot operate without taking into account the existence of two legal orders, the international one and the national one, and, as a result, the privileges of the international organisations concerned.

This can be demonstrated using the example of the European Public Prosecutor Office (hereinafter EPPO) that has been proposed on the level of the European Union. ${ }^{30}$ Unlike the INT or OLAF, the proposed EPPO would not be limited to cooperate with national law enforcement authorities, but would have the authority to investigate and prosecute fraud and other crimes affecting the interests of the European Union. At first glance, it could, thus, be argued

\footnotetext{
${ }^{28}$ Regulation (EU, Euratom) No 883/2013 of the European Parliament and of the Council of 11 September 2013 concerning investigations conducted by the European Anti-Fraud Office (OLAF) and repealing Regulation (EC) No. 1073/1999 of the European Parliament and of the Council and Council Regulation (Euratom) No. 1074/1999, OJ L $248,18.9 .2013$, p. 1 (hereinafter "OLAF Regulation").

${ }^{29}$ Article 1(3)(a) of the olaf Regulation.

${ }^{30}$ Proposal for a Council Regulation on the establishment of the European Public Prosecutor's Office, сом (2013) 534 final.
} 
that privileges of the European Union and its individual institutions, such as the European Commission, would not apply to the EPPO. If the European Union itself decides that extending EPPO's criminal investigation and powers to its institutions is necessary for the fulfilment of its functions, shielding the entire collection of information belonging to or held by the European Union and its individual institutions might be deemed no longer integral to ensuring its proper and independent functioning. ${ }^{31}$

At second glance, however, coercive investigative measures having the potential to violate the privilege of inviolability of archives would -as long as EPPO would be entitled to order them- still need to be carried out by national authorities. The reason for this is that EPPO would rely on a decentralised structure and national laws to investigate and prosecute fraud and other crimes affecting the financial interests of the European Union. Investigative measures ordered by EPPO and carried out by national authorities are not different from similar coercive investigative measures ordered by a national prosecuting office and executed by national authorities, to which the privilege of inviolability of archives undoubtedly apply.

Whilst the establishment of specific bodies dedicated to the fight against fraud and corruption within international organisations can, therefore, be described as focussing on the form of international organisations' cooperation, a possible duty on international organisations to cooperate with national law enforcement and judicial authorities in the specific context of privileges could shed light on its substance.

The question is whether such a duty exists. While it is discussed in legal doctrine whether a general duty to cooperate exists under customary international law, ${ }^{32}$ this duty would only apply to States who cooperate with each other by, inter alia, establishing international organisations, but not to the international organisations themselves. However, this does not prevent States from including in the founding treaties of international organisations an explicit duty on international organisations to cooperate with national law en-

\footnotetext{
${ }^{31}$ Similar considerations apply with regard to the United Nations in relation to an international tribunal set up by the United Nations itself. The Secretariat of the United Nations has taken the position that, in respect of the International Criminal Tribunal for the former Yugoslavia (hereinafter ICTY), the CPIUN applies to the United Nations' archives; see Muller, AleXander Samuel, "Immunities of ictr Staff Members, Assets and Archives before the ictr", en Richard May, et al. (eds.), Essays on icty Procedure and Evidence in Honour of Gabrielle Kirk McDonald, La Haya, Kluwer, 2001, pp. 439, 443 et seq.

32 Wolfrum, Rüdiger, "Cooperation, International Law of", en Rüdiger Wolfrum (ed.), Max Planck Encyclopedia of Public International Law, párr. 13 et seq. Disponible en: http://opil.ouplaw.com
} 
forcement and judicial authorities in the context of privileges. States can give and limit privileges to international organisations at the same time.

Striking examples in this regard are the United Nations and the European Union. Like the World Bank Group, the United Nations and the European Union enjoy the privilege of inviolability of their archives, but the United Nations is explicitly obliged to "co-operate at all times with the appropriate authorities of Members to facilitate the proper administration of justice, secure the observance of police regulations and prevent the occurrence of any abuse in connection with [...] privileges". ${ }^{33}$ In a similar vein, the institutions of the European Union are explicitly obliged, "for the purposes of applying [the] Protocol" (which lays down the privileges and immunities of the European Union) to "cooperate with the responsible authorities of the Member States concerned" ${ }^{34}$

Both duties to cooperate are, of course, very general and it is open to debate which individual duties can be derived from them in practice. However, comparable provisions on immunities give certain indications in this regard. For example, the Secretary-General of the United Nations has "the right and the duty to waive the immunity of any official in any case where, in his opinion, the immunity would impede the course of justice and can be waived without prejudice to the interests of the United Nations". ${ }^{35}$ Institutions of the European Union are obliged to waive the immunity of their officials or other servants wherever they consider "that the waiver of such immunity is not contrary to the interests of the Union". ${ }^{36}$ If the general duty of international organisations to cooperate with national law enforcement and judicial authorities in the context of privileges is interpreted in this systematic context, the following individual duties can be derived:

First, if national law enforcement and judicial authorities would like to access international organisations' archives, they must request-as opposed to compel as in the case of World Bank Group $v$. Wallace- international organisations to produce certain documents and must state why these documents are necessary for the "proper administration" or "course of justice", i.e. the investigation or prosecution in question. The last condition aims to prevent frivolous "fishing expeditions" into international organisations' archives. ${ }^{37}$ Although the

\footnotetext{
${ }^{33}$ Article v Section 21 cPIUn.

${ }^{34}$ Article 18 of the Protocol on the Privileges and Immunities of the European Union (hereinafter "Protocol") (OJ C 202, 7.6.2016, p. 266).

${ }^{35}$ Article VI Section 23 cPIUn.

${ }^{36}$ Article $17(2)$ of the Protocol.

${ }^{37}$ Muller, AleXander Samuel, "Immunities of icty Staff Members, Assets and Archives before the icty", en Richard May, et al. (eds.), Essays on icty Procedure and Evidence in Honour of Gabrielle Kirk McDonald, La Haya, Kluwer, 2001,
} 
duty to cooperate is only addressed to the international organisations, but not to the Member States, it is, therefore, not a one-way street that only imposes obligations on international organisations. The cooperation of international organisations presupposes that national authorities do not revert to coercive measures in order to access international organisations' archives, but take into account the fact that international organisations' archives are privileged and only request access.

Second, following such a request, international organisations must assess whether the production of these documents is contrary to their interests, for example because the documents contain confidential information. If this is the case, they may deny the request, but must state the reasons for the denial. However, if they come to the conclusion that the production of these documents is not contrary to their interests, they must fulfil their duty to cooperate by producing these documents. In this context, it is important to note that international organisations may have implicitly identified cases through the adoption of secondary law in which the production of documents to national law enforcement and judicial authorities is not contrary to their interests. An example of such an implicit identification is Regulation (EC) No. 1049/2001 of the European Parliament and of the Council of 30 May 2001 regarding public access to European Parliament, Council and Commission documents. ${ }^{38}$ However, the fact that international organisations have obliged themselves to comply with requests for access to documents does not mean that the privilege of inviolability of archives has become redundant. The fact that an international organisation obliges itself to grant access to documents within its own legal order may not be interpreted as meaning that this obligation may be enforced against it by national authorities.

In the case of World Bank Group $v$. Wallace, there is no explicit duty of the World Bank Group to cooperate with national law enforcement and judicial authorities. The World Bank Group has, however, voluntarily subscribed to cooperate with national law enforcement authorities in line with its official policy to fight fraud and corruption. If it pays more than lip service to this cooperation, it should also voluntarily subscribe to the individual duties derived from the explicit duty of some international organisations to cooperate with national law enforcement and judicial authorities in order to mitigate the risk of a catch-22 situation arising from the privilege of inviolability of archives.

${ }^{38}$ OJ L 145, 31.5.2001, p. 43. Because of its independence, the European Central Bank has adopted its own rules on public access (see Decision of the European Central Bank of 4 March 2004 on public access to European Central Bank documents, OJ L 80, 18.3.2004, p. 42). 


\section{Conclusion}

In contrast to Joseph Heller's novel 'Catch-22', the illogical or paradoxical problem or situation arising from the privilege of inviolability of archives in international organisations' cooperation with national in the fight against fraud and corruption is not one of bureaucratic absurdity, but one of different legal orders that are not necessarily aligned from the outset. This, however, does not mean that the illogical or paradoxical problem cannot be solved and ways found to bring the national legal order and the international legal order closer together. By doing so, solutions have to be found rather on the international level than on the national level.

National law enforcement and judicial authorities have to respect the privilege of inviolability of archives enjoyed by international organisations and may neither interpret the privilege restrictively without taking full account at the same time of the purpose of privileges, i.e. the orderly and independent operation of international organisations, nor generally limit the privilege in any other way. It therefore lies in the hands of international organisations themselves to limit the risk of a catch-22 situation arising from the privilege of inviolability of archives in their cooperation with national authorities. With regard to the procedure for such cooperation, they may establish specific bodies dedicated to the fight against fraud and corruption. With regard to the more important substance of such cooperation, international organisations must make reasonable use of the privilege. However, the onus is not only on international organisations. Any reasonable use of the privilege presupposes that national law enforcement and judicial authorities acknowledge its existence and deal with it respectfully.

\section{Bibliography}

Articles of Agreement of the International Bank for Reconstruction and Development, unTs, vol. 2, p. 13.

Articles of Agreement of the International Development Agency, unTs, vol. 439, p. 249.

Carpanelu, Elena, "On the Inviolability of Diplomatic Archives and Documents: The 1961 Vienna Convention on Diplomatic Relations to the Test of Wikileaks", Rivista di diritto internazionale, vol. 98, 2015, p. 834.

Charter of Fundamental Rights of the European Union, OJ C 202, 7.6.2016, p. 389.

Convention on the Privileges and Immunities of the United Nations, unTs, vol. 1, p. 15.

Court of Appeal for England and Wales, R. (Bancoult) v. Secretary of State for Foreign and Commonwealth Affairs (No. 3), 2014 ewCA Civ 708, 1 W.L.R. 2921. 
Court of Justice of the European Union, Judgment of 17 June 1981, Case 113/80, Commission v. Ireland, EU:C:1981:139.

DAHER, AYMAN \& SARHAN, AlAN, "World Bank Group v Wallace: International Organizations' Immunities and their Involvement in the Fight Against Corruption”. Disponible en: http://www.brettonwoodslaw.com/ world-bank-group-v-wallace-international-organizations-immunities-and-their-involvement-in-the-fight-against-corruption.

Decision of the European Central Bank of 4 March 2004 on public access to European Central Bank documents, OJ L 80, 18.3.2004, p. 42.

European Court of Human Rights, Judgment of 18 February 1999, Beer and Regan v. Germany, Merits, App No 28934/95, ECHR 6, 1999.

European Court of Human Rights, Judgment of 18 February 1999, Waite and Kennedy $v$. Germany, Merits, App No 26083/94, ECHR 13, 1999.

Herdegen, Matthias, "Interpretation in International Law", en Rüdiger Wolfrum (ed.), Max Planck Encyclopedia of Public International Law. Disponible en: http://opil.ouplaw.com

Inter-American Court of Human Rights, Judgment of 25 November 2003, Myrna Mack Chang v. Guatemala, Series C, No. 101.

Inter-American Court of Human Rights, Judgment of 29 November 2006, La Cantuta $v$. Peru, Series C, No. 162.

Inter-American Court of Human Rights, Judgment 26 September 2008, Tiu Tojín $v$. Guatemala, Series C, No. 190.

Inter-American Court of Human Rights, Judgment of 23 November 2009, Radilla Pacheco v. Mexico, Series C, No. 209.

Inter-American Court of Human Rights, Judgment of 24 November 2010, Gomes Lund et al. v. Brazil, Series C, No. 219.

MöLDNER, MiRKA, “International Organizations or Institutions, Privileges and Immunities”, en Rüdiger Wolfrum (ed.), Max Planck Encyclopedia of Public International Law. Disponible en: http://opil.ouplaw.com

Muller, Alexander Samuel, International Organizations and their Host States, Aspects of their Legal Relationship, La Haya, Kluwer, 1994.

Muller, Alexander Samuel, "Immunities of icty Staff Members, Assets and Archives before the Iсту”, en Richard May, et al. (eds.), Essays on icty Procedure and Evidence in Honour of Gabrielle Kirk McDonald, La Haya, Kluwer, 2001, p. 439.

Orakhelashvili, Alexander, "State Immunity in National and International Law: Three Recent Cases Before the European Court of Human Rights", Leiden Journal of International Law, vol. 15, 2002, p. 703.

Proposal for a Council Regulation on the establishment of the European Public Prosecutor's Office, сом (2013) 534 final.

Protocol on the Privileges and Immunities of the European Union, OJ C 202, 7.6.2016, p. 266. 
Regulation (EC) No. 1049/2001 of the European Parliament and of the Council of 30 May 2001 regarding public access to European Parliament, Council and Commission documents, OJ L 145, 31.5.2001, p. 43.

Regulation (EU, Euratom) No. 883/2013 of the European Parliament and of the Council of 11 September 2013 concerning investigations conducted by the European Anti-Fraud Office (OLAF) and repealing Regulation (EC) No. 1073/1999 of the European Parliament and of the Council and Council Regulation (Euratom) No. 1074/1999, OJ L 248, 18.9.2013, p. 1.

Supreme Court of Canada, World Bank Group v. Wallace, 2016, scc 15, 20161 S.C.R. 207. Disponible en: https://scc-csc.lexum.com/scc-csc/scc-csc/en/ item/15915/index.do

Vienna Convention on Diplomatic Relations, unTs, vol. 500, p. 95.

Vienna Convention on Consular Relations, unTs, vol. 596, p. 261.

Vienna Convention on the Law of the Treaties, UnTS, vol. 1155, p. 331.

Wickremasinghe, ChanaKa, "International Organizations or Institutions, Immunities before National Courts”, en Rüdiger Wolfrum (ed.), Max Planck Encyclopedia of Public International Law. Disponible en: http://opil.ouplaw.com

Wolfrum, RÜDIGER, “Cooperation, International Law of”, en Rüdiger Wolfrum (ed.), Max Planck Encyclopedia of Public International Law. Disponible en: http://opil.ouplaw.com 